\title{
Exposing Gender Inequalities: Impacts of Covid-19 on Aotearoa I New Zealand Employment
}

\author{
ANNICK MASSELOT* and MARIA HAYES ${ }^{* *}$
}

\begin{abstract}
This article outlines how the Covid-19 pandemic exacerbates economic and social gender inequalities in Aotearoa I New Zealand. While this crisis highlights the central part played by women in the economy, the gender impacts of the pandemic are visible in connection to a decrease in job security and financial safety for female workers; to a rise in the duplication of paid and unpaid work; to an increase violence in and outside of homes; a heightened risk exposure to the virus and worse health outcomes. Not all women are equally positioned in this crisis, women of Māori and Pacific descent are disproportionately feeling the effects of the pandemic.

The two-prong, government's recovery plan, which only partially ensures a fair and equal economic rebuild, is critically assessed. While the economic response fails to take a systematic gender approach, scope for challenging traditional gender assumptions is met head-on in relation to policy on violence against women. The article considers flexible working options and focuses on options for reframing employment law in a post-pandemic environment with a view to achieve and deliver equality between men and women through an intersectional lens.
\end{abstract}

Keywords: gender inequality, vulnerability, covid-19, abuse, violence, care, economic recovery bias

\section{Introduction}

"The pandemic is exposing and exploiting inequalities of all kinds, including gender inequality" (Guterres, 2020).

The Covid-19 pandemic is severely affecting public health and is bringing about unprecedented disruptions to economies and labour markets. It has exposed prevalent vulnerabilities in the social, political and economic structures, which, in turn, the impacts of the pandemic are amplifying. Gender issues, in particular, are at the very core of the Covid-19 pandemic. If anything, this crisis has highlighted the central part played by women in the economy. The essential workers who supported society and the economy through the worst of the pandemic were not employed in those sectors of the economy that are rewarded with high wages. It has surprised many that a feminised and racialised workforce has not only supported the country during the Covid-19 crisis, but it was those same individuals who, due to the nature of their work, risked highest exposure to the virus and, therefore, have worse health outcomes. Women are more likely than men to be negatively affected in multiple and compounded ways, including a duplication of paid and unpaid work. The nationwide lockdown lockdown (25 March-13 May 2020), as a policy response to the pandemic, has also contributed to increase women's vulnerability to violence; and post-lockdown, they are likely to be hardest hit by the economic downturns. In this context, women of Māori and Pacific descent are disproportionately

\footnotetext{
* Professor of Law, University of Canterbury, New Zealand

** Research Assistant, University of Canterbury, New Zealand
} 
felling the effects of the pandemic, as they are often predominantly susceptible to job losses due to the nature of their employment fields.

Covid-19 is exacerbating economic and social gender inequalities. In particular, the gender impact of the pandemic is visible in connection to a decrease in job security and financial safety for female workers. Female dominated industries, such as retail, tourism and hospitality, have heavily been affected by the pandemic and are likely to see the most redundancies, severely affecting the financial position of many women in Aotearoa I New Zealand (Whiteford \& Olsen, 2020). At the same time, the closure of schools, day care centres and other childcare options unavailable during lockdown has affected women's ability to reconcile work and family, despite the fact that many men/fathers were also confined at home. This has led to an increase in the "second shift" (Hochschild \& Machung, 1989) and the "third shift", involving managing the emotions that getting through your first and second shift inspired - the intense feelings of guilt and resentment that women began to feel as they realised that "having it all" often just meant "doing everything" (Hochschild, 1997).

The lockdown period also saw an increase in the violence endured by women both at home and at work. The existing issues of domestic violence in Aotearoa I New Zealand have become more severe as women were confined with perpetrators of intimate violence (Kronast, 2020). Furthermore, essential workers have endured violence and risk at work throughout lockdown. These issues, in conjunction with the effects of the economic downturn, highlight the unique nature of the pandemic, which has been referred as a "pink-collar recession" (Ribeiro, 2020).

The aim of this paper is to address the gender impacts of Covid-19 in relation to employment and labour law. This paper is divided into three sections. Section one highlights the gender inequities resulting from Covid-19. Section two discusses the government's recovery plans and how women may be included in policy to ensure a fair and equal economic rebuild. Section three considers issues for women in a post-Covid-19 employment market, with considerations around flexible working options and a focus on reframing the debate to achieve and deliver equality between men and women through an intersectional lens.

\section{Gender Inequality and vulnerability as a result of Covid-19}

\section{Occupational safety and health risks}

Amidst the economic, social and health disruptions, women have been central to the fight against Covid-19 and, in doing so, they are facing increased occupational safety and health risks. Women make up the majority of the health and social care workers in Aotearoa I New Zealand, placing them at the frontline of the pandemic. As a result, women have become the most affected by Covid-19, making up 56 per cent of the total cases in Aotearoa I New Zealand (Ministry of Health, 2020). This contrasts to early evidence which suggests that men are more at risk of contracting the virus based on a number of factors including: non-communicable diseases, unhealthy lifestyles and disparities in men's immune systems compared to women's (Devlin, 2020). However, occupational sex-segregation has meant that women have disproportionately been put at risk of greater exposure as healthcare (nurses, midwives and community healthcare workers) and supermarket workers are those on the frontline (UN Women, 2020). Although women are most affected by the pandemic in terms of occupational safety and health risks, they often are overlooked in decision making around responses to Covid-19 (UN Women, 2020). A lack of gender mainstreaming practices and scarcity of women in decision-making power explain the disparity. While globally women consist of over 76 per cent of 
medical doctors and nurses, they represent only a minority in senior or leadership positions within health sectors (Boniol et al., 2019).

During the Covid-19 pandemic, the meaning of an essential worker has been redefined to not only include care and health but also supermarket workers (Payscale, 2020). These workers, who are in majority female, are largely on minimum salaries which do not meet the living wage (\$21.15) (AshbyCoventry, 2020). Despite taking the risk to serve the public, being granted essential status and showing loyalty to their employers, supermarket workers were poorly rewarded during the period of lockdown when they were granted a mere 10 per cent pay increase, which was then withdrawn at the end of lockdown.

Women, from a range of employment sectors, have been exposed to harmful outcomes because of the pandemic. Sex workers, another vulnerable group, struggled to balance their personal safety with clients' confidentiality. As agreed between the Prostitutes' Collective and Worksafe, sex workers were advised to collect the date, time, location of bookings, client's name, phone number and email address in order to comply with contact tracing requirements (Todd, 2020). In reality, many sex workers worked without proper contact details because, faced with financial hardship, they had no other option to support themselves and potentially their family. In addition, the Prostitutes Collective issued guidelines including no kissing and avoiding people's breath (RNZ, 2020a), which appeared unreasonable considering the nature of the work.

\section{The value of care}

While the majority of essential workers are female, during lockdown, women in general have also provided the bulk of unpaid work at home, as well as the duties of home-schooling due to the closure of schools and daycare centres. As intergenerational care, in particular, care provided by grandparents, was discouraged due to lockdown and the risk of virus transmission, causing high mortality rates in the older generation, work-life reconciliation was, therefore, particularly difficult for essential workers. Women, who were able to work from home, also faced the difficult balancing act of juggling unpaid care roles, home-schooling duties and paid work. Data from the UK shows that regardless of whether they were in paid employment, mothers carried out 30 per cent more home-schooling duties than fathers during lockdown (Lewsey, 2020).

Women's unpaid care work has long been a driver of inequality (see Caracciolo di Torella \& Masselot, 2020). The Covid-19 pandemic is contributing to exacerbate invisible labour and unpaid domestic work, placing greater burdens on women. More than ever, there is a need for policies to be structured around recognising and supporting unpaid care and domestic work undertaken by women (Russell $\&$ Masselot, 2020). Although women have disproportionately been carrying the double burdens of paid employment and unpaid work during lockdown, the pandemic has also enabled men to be exposed to unpaid care work (Alon et al., 2020). In turn, the increase in domestic work by men during Covid-19 may help to shift longstanding gender norms around care and domestic work.

\section{Unemployment}

Although the pandemic has affected the economy as a whole, particular sectors, such as manufacturing, retail, accommodation or food, are considered high-risk sectors, which have a sizeable share of female employment. The economic disruptions caused by the Covid-19 pandemic is currently resulting in thousands of women losing their jobs. Statistics New Zealand released data on $5^{\text {th }}$ August showing that the impact of Covid-19 on Aotearoa I New Zealand jobs during the June 2020 quarter was 
disproportionately felt by women (Stat NZ, 2020). Over that period, out of 11,000 people who had lost their job, 10,000 were women.

With the closure of all unessential businesses over the nationwide lockdown, accommodation and retail sectors were hit hard by Covid-19. In turn, these industries are the most susceptible to redundancies, with more than 53,000 jobs estimated to be lost in the accommodation and retail sector between March 2020 and March 2021, amounting to a third of all jobs (Whiteford \& Olsen, 2020). Women represent 57.6 per cent of the retail and accommodation industry, with 18.9 per cent of the female workforce employed in those areas, compared to 13.5 per cent of the male workforce (Johnston, 2020). Consequently, in relation to unemployment, women are definitely more affected by Covid-19 than men.

\section{Gender and old age}

The superannuation scheme, KiwiSaver, was designed to secure an individual's retirement savings until the age of 65. However, in times of significant financial hardship, individuals may access their savings early. Amongst the lockdown period and in response to hardship concerns, KiwiSaver loosened the rules around early access, making it possible for struggling individuals to obtain their funds during lockdown (Inland Revenue, 2020). Subsequently, it was reported that there had been a significant increase in hardship withdrawal requests (Stock, 2020). Despite the short-term relief, it is evident that early access to superannuation may pose issues for individuals in the future, especially for women. Women earn less, save less and hold less secure jobs, and they have less access to social protection. Their capacity to absorb economic shocks is, therefore, less than that of men. While the superannuation scheme offers a universal pension, women tend to have less net wealth at the age of retirement than men (Women in Super, n.d.). This is mainly due to the care responsibilities that women carry compared to men, which creates fewer opportunities for women to either work full time or progress in their careers. In turn, women are subject to less income, constituting a gender pay gap. Therefore, as women are already likely to have less retirement savings than men, the option of early access may significantly disadvantage women later on in life. There will be long-term consequences for any individual who decides to access their KiwiSaver early. However, the effects are greater for women. Compared to men, women live an average of six to eight years longer, meaning they have to stretch out their savings for a greater period of time (WHO, n.d.). As women are also likely to have less net wealth, they are left with worse financial outcomes than men, even throughout the period of retirement. A potential consequence of early access may be that women have insufficient funds within KiwiSaver to support them throughout retirement. Despite the entitlement to a state pension, individuals with expenses and mortgage payments may not be able to make ends meet with those weekly payments. Ultimately, women may be forced to engage in employed work throughout old age.

\section{Violence and Abuse}

The impacts of the pandemic have amplified existing forms of gender violence in Aotearoa I New Zealand. It is worth noting that Aotearoa I New Zealand has one of the highest rates of intimate partner violence in the world, which disproportionately affects women (Family Violence Death Review Committee, 2014). The legal obligation to remain confined at home has placed women at increased risks of intimate partner violence. Over the period of lockdown, New Zealand Police reported a 20 per cent increase in calls relating to domestic violence and a 22 per cent increase in investigations.

Alongside the increase in domestic violence, there has been increase in abuse at work. In addition to risking their own health to enable the functioning of essential services, essential hospital and supermarket female workers have been exposed to further harm in the form of abuse and harassment. 
Evidently, women are the most vulnerable to such abuse as they represent a majority of employees in both the healthcare and supermarket sector. Employees in both professions have spoken out about the verbal abuse and threats. In particular, supermarket staff commented on the increase of racial abuse, spitting and name calling endured during lockdown as well as the harassment for not wearing masks or gloves, despite this not being a legal requirement (RNZ, 2020b). Healthcare workers, particularly nurses, have also reported being subject to verbal and physical assaults by patients demanding Covid19 swabs. Although such form of violence against health workers have been reported in the past, the pandemic has exacerbated the problem (Ball, 2020).

\section{Impact of Covid-19 on Māori and Pacific Women in Aotearoa}

Looking at past crises helps anticipate the extent of harm the pandemic is likely to have on Māori and Pacific women. The recession that flowed from the Global Financial Crisis of 2008 disproportionately affected Māori and Pacific women. The unemployment rate of Māori and Pacific women was more than double than the rate of Pākehā women (Ministry for Women, 2020). Māori and Pacific women were not only hit the hardest by the recession, but they also took the longest to recover. The Covid-19 crisis is likely to amplify the existing gap in equality between Pākehā, Māori and Pasifika people in relation to employment, general standards of living and the health sector (Scobie \& Sturman, 2020). Māori and Pacific People represent 14 per cent of the population in Aotearoa. Yet they are likely to be disproportionately impacted by the economic downturn (Ministry of Health, 2020). While Māori and Pacific women experience unemployment at over double the rate for all women, the Covid-19 crisis is likely to increase this divide because these women are concentrated in sectors which are vulnerable to the economic downturn, such as sales, tourism and low-skilled manual operations (Ministry for Women, 2016). They are also well-represented in the aged-care sector, where, in addition to economic vulnerability, Māori and Pacific women face increased risk exposure to Covid-19.

While the effects of the pandemic and the potential loss of employment is likely to be severe for Māori and Pacific women, these women also tend to carry more substantive care responsibilities than Pākehā women, through the care and financial support provided to extended family members (Ministry for Women, 2020). Moreover, unpaid labour, which is carried out by Māori women in maraes, is yet to be acknowledged. Therefore, the economic downturns of Covid-19 will likely place massive strains on these families.

\section{Government initiatives towards rebuilding the Aotearoa I New Zealand's economy}

Previous recessions have shown that blue-collar or lower-income men were most likely to suffer from unemployment. For instance, the 2008 Global Financial Crisis was characterised by significant job losses in male-dominated industries such as construction and manufacturing. The corresponding recovery efforts has improved men's employment at a rate faster than that of women's (Périver, 2014). In contrast, the Covid-19 pandemic is resulting in a so-called "pink-collar recession", leaving thousands of women jobless and with substantially more unpaid care work. The challenge for Aotearoa I New Zealand as it emerges from Covid-19 lockdown will be to design a targeted gendered approach to economic recovery. This will be crucial to make sure that women recover from this crisis because "an economy which leaves women and girls behind will fail to recover at all" (Smether, as cited in Ipsos MORI, 2020). This approach will need to include the diversity of women in Aotearoa. As unemployment rates begin to increase as a result of the Covid-19 pandemic, the government must be aware of the severe effects upon Māori and Pasifika women and provide targeted recovery, which 
specifically accounts for these women in the economic rebuild, in order to mitigate and reduce the inequality gap.

The government has responded fast to the economic crisis precipitated by the Covid-19 pandemic. In this context, two sorts of financial supports have been provided to respectively bolster and enhance employment rate on the one hand, and to combat violence against women on the other. From a gender perspective, these responses have failed to take a systematic gender approach. Work is still only considered as paid work done in a public space by men. Thus, despite the clear disproportionality between men and women as a result of Covid-19, the economic recovery is being framed to improve outcomes for men. Women continue to be associated with the private sphere, doing work that remains invisible and unaccounted for in traditional accounting (Waring, 1988). Such policy design denotes a level of continuity in terms of gendered assumptions. In contrast, the government's response in relation to domestic violence demonstrates that there is scope for challenging traditional gender assumptions. The next section looks at these two types of responses in turn.

\section{i. $\quad$ Economic Recovery Plans- Biased towards Male Dominated Workforces?}

In response to the economic fallout following Covid-19, the Aotearoa | New Zealand government announced a $\$ 50$ billion fund to rescue the economy and bring the unemployment rate back up to 4.2 per cent within two years. One of the initiatives which government has implemented is the investment of $\$ 3.3$ billion into infrastructure projects, which are to be fast tracked under legislation currently going through Parliament (Logan, 2020). This initiative, termed the "Shovel-Ready Projects", aims to create jobs by stimulating the workforce, in particular, the construction industry, and by supporting the broader community. Despite the benefits this scheme will provide to the construction, forestry, electricity, gas, water and waste industries, it appears that lack of consideration has been given to the economic recovery of women's employment. The Shovel-Ready Projects target workforces which are largely dominated by men, as women merely represent 14.4 per cent of the construction industry (Johnston, 2020). Women also only represent 24.5 per cent of the electricity, gas, water and waste services employees (Johnston, 2020). Although it is acknowledged that a large number of ancillary jobs will be created as a result of the Shovel-Ready Projects, it is unlikely that this initiative will enable the economy to rebuild in a way which promotes gender equality, because the recovery strategy has not been designed using a gendered lens (Johnston, 2020).

The lack of consideration for women in the economic rebuild raises a number of gender issues. The failure to explicitly include women in the recovery strategies risks widening the gender divide, best illustrated by the gender pay gap, which was set at 9.3 per cent in the June 2019 quarter (Stats NZ, 2009). This gap exists despite the fact that women make up almost half of the paid workforce in Aotearoa I New Zealand (48 per cent). Yet strategies and recovery initiatives are still directed towards male-dominated industries, ignoring the need to support women's employment. Access to flexible working arrangements, family leave and the availability, quality and affordability of care support are essential measures to support women into paid employment (Masselot, 2015). Without adequate access to care support, women risk being forced back to the 1950s model of supporting male paid employment as housewife and child minders. Modern societies like Aotearoa I New Zealand with fluid family formation have high rates of single parent families, often women alone, who have to reconcile paid work with unshared care (Ministry of Social Development, 2019). The efforts put in by generations of women for gender equality could potentially be undone by the failure to include women in economic recovery plans. A prospective return to the male breadwinner / female homemaker model is shilling from a feminist perspective. Therefore, the lack of a gendered lens in designing the recovery strategy increases risks that women lose the ability to support themselves and their families, stripping them of their independence (Johnston, 2020). 
The recovery initiative further highlights the inadequacy to provide gendered responses in situations of crisis and urgency. The Christchurch Earthquakes should have served as lessons that women need to be explicitly considered and welcomed as applicants for roles which are generally undertaken by males (Mau, 2020). Women must be included in targeted recruitment training and considered for skills matching. Despite the $\$ 1.6$ billion trades and apprentice training package put in place for New Zealanders, there has been little effort to encourage women to undertake these courses and upskill themselves in order to benefit from the recovery packages (Beehive, 2020a). Much of this issue is put down to the lack of guidance in the budgeting process. In a time of crisis, it is especially necessary for agencies to consider who exactly will benefit from these policies and how they can be used to overcome inequalities. A gender mainstreaming policy would involve explicit and systematic process to ensure that women and marginalised groups are accounted for (Johnston, 2020).

\section{ii. $\quad$ Gendered response to violence}

The Covid-19 government response includes legal and budgetary provisions toward tackling increased violence against women resulting from lockdown. Unlike the economic response, this initiative is built on existing strategies that place gender at the centre of the policy design. In recognition of the deplorable rates of violence against women in Aotearoa I New Zealand, the Domestic Violence Victims' Protection Act, adopted in 2018, aims to help victims of violence remain in employment and find a way out of violence (NZ Law Society, 2018; Masselot, 2020). The effects of intimate violence is recognised to cause disruptions to individuals' employment as they may be taking significant amounts of leave to recover and/or attend essential appointments (Lloyd, 2002).

In response to the rise in domestic violence during lockdown and building on the 2018 Act, the government is allocating substantive funding towards the support of services for victims or survivors of family violence (Ministry of Social Development, 2020). The package includes services for perpetrators and provides a long-term approach to ensure safer and healthier homes (Beehive, 2020b).

These legal and budgetary initiatives aim to not only provide women with the essential support needed, but also contribute to a reduction family and sexual violence. The allocation of funds towards the issue of domestic violence is especially significant in this period of economic crisis as it aims to aid women's recovery from the mental and physical effects of violence, enabling them to gain independence and get back on their feet. In a time of economic uncertainty, it is important that victims of family violence are supported in the employment field to ensure they are not faced with compounded disadvantages, such as loss of hours or redundancies.

Additionally, and in response to increase in abuse at work, an amendment to the Protection of First Responders Bill is currently being considered by the Select Committee. This Bill will see a mandatory minimum prison sentence of six months for those who intentionally injure healthcare and emergency workers (Ball, 2020).

\section{Keys issues for women in a post-Covid-19 employment market: reframing the debate}

Despite funding made available towards safer environments and better outcomes in cases of intimate violence, women remain broadly unaccounted for economically within the 2020 Budget. Women are facing multiple disadvantages, as they are not only susceptible to family violence but are also facing unemployment. At the same time, Covid-19 has exacerbated women's unpaid work, which plays a 
significant part in the Aotearoa I New Zealand economy, especially in this time of crisis. It is, therefore, crucial to address unpaid work (Mau, 2020) with a view to combat ongoing and widening gender inequalities. An emerging form of gender mainstreaming has started at the Ministry for Women, which has developed a gender analysis tool to ensure that policies are implemented using a gendered approach. Gender mainstreaming has the potential to change the way we do and think about decisionmaking and the economy (Masselot, 2019). Gender mainstreaming has the potential to not only stimulate a decrease in the gender gap, but could also be beneficial towards the growth of the economy through the increase of individuals in paid employment (Ministry for Women, n.d.).

Uncovering the gendered consequences of Covid-19 is to expose the lack of value placed on care work and caring. The gendered and ethnic nature of this work only highlights the deep-rooted nature of socio-economic hierarchies in contemporary Aotearoa I New Zealand society. Covid-19 provides new prospect to shape a new kind of society, characterised by inclusiveness, solidarity and sustainability. As Aotearoa I New Zealand emerges from Covid-19 lockdown, it has the opportunity to embed an ethic of care into the current economic model. This final section considers reframing employment law inclusively.

\section{Flexibility}

The Covid-19 response and the requirement of social distancing has contributed to a large national workplace/work organisation experiment. Record numbers of people have been and are still, not only working from home, but there has been "staggered and rearranged shifts, reorganisation of the deployment of labour around continually improvised new systems of production, distribution and exchange demanded in a health and economic crisis" (Badham, 2020). In turn, this has resulted in major physical transformed workplaces in living western memory.

Flexibility has been key to this transformation during lockdown. Now, in a managed and internally open post-lockdown economy, there is an impending opportunity and necessity to restructure the Aotearoa | New Zealand economy for recovery. Prime Minister Jacinda Ardern has suggested that employers should consider a four-day working week together with other flexible working options as a way to boost tourism and help employees address persistent work-life balance issues (Ardern, 2020). Arguably, a four-day work week could go beyond supporting the tourism industry as well as family and social lives, and could also benefit mental and physical health, the environment, as well as climate change. Such uncommon policy ambition would "upends four decades of neoliberal insistence that workplace 'flexibility' is the purview only of employers" (Badham, 2020). We are not yet there. Ardern only suggested that employers who can, should think about this kind of flexibility. There is no policy proposal at this stage nor is there plan to regulate flexible work.

While many have enjoyed the newfound work flexibility in lockdown and are keen to expand it to the post-lockdown period, a four-day work week has not been universally helpful. It is worth noting that not all workers were able to work from home, leading to thorny work-family conflict during lockdown. In addition, for the workers that had to work from home, flexibility did not comprehensively result in a better life. Working from home has emphatically underscored yet more gender, ethnic and class disparities in relation to unpaid work and care within the home, and for some violence. The concept of "flexibility" as flowing from the Covid-19 lockdown has not been thought through with (gender) equality in mind. This means that as schools and day care centres closed, female workers have had to face the dual burden of unpaid and paid work in their home environment. Depending on other intersectional considerations, these women have had constrained space, time, resources and/or support to balance work and care. Thinking forward about flexible work environments, which could contribute to effective gender equal work-life balance, will require an understanding of the relationship between 
flexibility and the public/private divide. I have argued elsewhere that actual and fair work-life reconciliation can only be successful if flexibility is matched with legal provisions to support leave from work for care as well as adequate, affordable and quality care facilities (Caracciolo di Torella $\&$ Masselot, 2010). In this context, it is important to emphasise that care has to be broadly construed to not only cover childcare but also other forms of care including adults, disability and long terms care (Caracciolo di Torella \& Masselot, 2020).

As a policy reform, a universal four-day work week is unlikely to provide answers to work-life balance or to contribute effectively to the economic recovery. The diversity of the workforce means that while some workers would benefit from a form of vertical time reduction (a four-day work week), others would gain from horizontal time reductions constituted of shifts with fewer hours. Others, yet would be happier working full-time from home. Combinations of variable forms of flexibilities over work, time and space might better benefit employees' personal life cycle and enhance their productivity.

\section{A feminised approach to work}

This crisis is set apart from previous crises in that it has highlighted the crucial role played by women in the economy. The essential paid workers (nurses, teachers, retail workers, early learning workers, aged care and community workers, cleaners) are disproportionately female. To add to this, the essential unpaid care and work done in the home is also done by women. Both work, paid and unpaid, has systematically been under-valued, disrespected ignored and rendered invisible in the official accounting of the economy. In her 1988 seminal book, Counting for nothing: What men value and what women are worth, Marilyn Waring shows how national income accounting became infused with the patriarchal values dominant during its post-World War II development. She sat the foundation for the development of feminist economics as a discipline, which aims to explore the implications of discounting the work of half the world's population and to challenge the assumptions on which power rests. These gender biased assumptions are enduring as illustrated by the present day government response to economic downturns. Yet the makeup of the key workers should bring renewed ways of thinking about the value of work to include production and reproduction.

A holistic and feminist approach to work is, therefore, needed. In practice, a holistic approach involves rethinking the meaning of work as to include unpaid care and "develop a legal system that acknowledges, promotes and protects the caring relationship in general and carers in particular" (Caracciolo di Torella \& Masselot, 2020, p.156). In order to do this, the law must be underpinned by strong fundamental values and an ethic of care, which is based on the idea that life is a series of mutual and interdependent relationships without which we would not exist (Meyers, 2004).

\section{Conclusion}

Covid-19 has underscored the fundamental role that women play in the economy. Yet women are hit the hardest by the Covid-19 pandemic, because of their crucial but undervalued and unaccounted involvement in the economy. They are also enduring gender biased assumptions, illustrated by the present-day government response to economic downturns. Not only have women been subject to a greater risk of contracting the virus, they are also more likely than men to be subject to unemployment and vulnerability due to their involvement in precarious work. Work done by women has been systematically undervalued, disrespected, ignored and rendered invisible in the official accounting of the economy. To top it off, violence against women remains persistent at home and work. These issues all contribute to the risk of further widening the gender equality gap. 
The makeup of key workers should bring renewed ways of thinking about the value of work to include production and reproduction. Such a reflection on the economy and the law could be underpinned by the theory of an ethics of care. This involves taking a gendered approach. It implies considering whether families are supported in terms of childcare. It also means that policy targets sectors and industries which equally benefit women and men. Overall, Aotearoa I New Zealand must use a gendered lens to guarantee there is no step back in delivering gender equality by leaving women out of the economic rebuild. In order to properly rebuild the economy, women must be included in the design. The work done and the risk taken by women for us all call for opportunities and policies to be implemented with a gendered approach. It is crucial that issues around women's employment are seriously addressed and considered for fear of undoing the gains of many generations of feminists.

\section{References}

Alon, T., Doepke, M., Olmstead-Rumsey, J., \& Tertiltt, M. (2020). The impact of COVID-19 on gender equality. VOX EU, CEPR. https://voxeu.org/article/impact-coronavirus-pandemicgender-equality

Ardern, J. (2020, May 20). Just finishing up a visit in Rotorua [Video]. Facebook. https://www.facebook.com/watch/live/?v=236345824321997\&ref=search

Badham, V. (2020, May 21). 'Snap back'? Jacinda Ardern snaps forward with a four-day week: no wonder she's popular. The Guardian.

https://www.theguardian.com/commentisfree/2020/may/21/snap-back-jacinda-ardern-snapsforward-with-a-four-day-week-no-wonder-shes-popular

Ball, D. (2020). Nurses to get more protection added to 'First Responders' legislation. The National Tribune. https://www.nationaltribune.com.au/nurses-to-get-more-protection-added-to-firstresponders-legislation/

Beehive. (2020a). Free trades training to support New Zealanders into work. https://www.beehive.govt.nz/release/free-trades-training-support-new-zealanders-work

Beehive. (2020b). Next steps to end family and sexual violence: Budget 2020.

https://www.beehive.govt.nz/release/next-steps-end-family-and-sexual-violence-budget-2020

Boniol, M., McIsaac, M., Xu, L., Wuliji, T., Diallo, K., \& Campbell, J. (2019). Gender equality in the health workforce (Working Paper 1, WHO/HIS/HWF/Gender/WP1/2019.1). World Health Organization (WHO). https://apps.who.int/iris/bitstream/handle/10665/311314/WHOHIS-HWF-Gender-WP1-2019.1-eng.pdf?ua=1

Coventry-Ashby, E. (2020, May 25). Living wage advocate's concern for supermarket workers. Stuff. https://www.stuff.co.nz/timaru-herald/news/121542689/living-wage-advocatesconcern-for-supermarket-workers

Devlin, H. (2020, April 16). Men are more likely to die from coronavirus - but why? The Guardian. https://www.theguardian.com/world/2020/mar/26/men-are-much-more-likely-to-die-fromcoronavirus-but-why 
Caracciolo di Torella, E., \& Masselot, A. (2020). Caring responsibility in EU law and policy: who cares? Routledge

Family Violence Death Review Committee. (2014). Fourth Annual Report: January 2013 to December 2013. Wellington: Health Quality and Safety Commission https://www.hqsc.govt.nz/assets/FVDRC/Publications/FVDRC-4th-report-June-2014.pdf

Guterres, A. (2020). "The pandemic is exposing and exploiting inequalities of all kinds, including gender inequality". UN. https://www.un.org/en/un-coronavirus-communicationsteam/pandemic-exposing-and-exploiting-inequalities-all-kinds-including

Hochschild, A. (1997). The Time Bind. WorkingUSA, July/August, 21-29.

Inland Revenue. (2020). COVID-19 Kiwisaver. https://www.ird.govt.nz/covid-19/individuals-andfamilies/kiwisaver

Ipsos MORI. (2020). 6 in 10 women finding it harder to stay positive day-to-day due to coronavirus. https://www.ipsos.com/ipsos-mori/en-uk/6-10-women-finding-it-harder-stay-positive-dayday-due-coronavirus

Johnston, K. (2020, May 22). Covid19 Coronavirus: Government's economic response slammed for favouring men. New Zealand Herald.

https://www.nzherald.co.nz/nz/news/article.cfm?c_id=1\&objectid=12333730

Kronast, H. (2020, April 10). Increase in family violence during coronavirus lockdown. Newshub. https://www.newshub.co.nz/home/new-zealand/2020/04/increase-in-family-violence-duringcoronavirus-lockdown.html

Lewsey, F. (2020). Women bear brunt of coronavirus economic shutdown in UK and US. University of Cambridge. https://www.cam.ac.uk/research/news/women-bear-brunt-of-coronaviruseconomic-shutdown-in-uk-and-us

Lloyd, S. (2002). The effects of domestic violence on women's employment. Law and Policy, 19(2), $139-167$

Logan, T. (2020). 'Shovel-ready' projects ignore important aspects of community resilience. University of Canterbury. https://www.canterbury.ac.nz/news/2020/shovel-ready-projectsignore-important-aspects-of-community-resilience.html

Masselot, A. (2015). Gender implications to the right to request flexible working arrangements: Raising pigs and children in New Zealand. New Zealand Journal of Employment Relations, 39(3), 59-71

Masselot, A. (2019). Visions for gender equality post-2020: How to improve the interaction between legal instruments (EU acquis) and policy-making (communication, funding programme, European semester)? In N. Crowley \& S. Sansonetti (eds.), New visions for gender equality 2019 (pp.9-13). Luxembourg: Publications Office of the European Union. https://ec.europa.eu/info/sites/info/files/saage_report-new_visions_for_gender_equality2019.pdf 
Masselot, A. (2020). Employment law. New Zealand Law Review, 2(21), 257-277

Mau, A. (2020, May 17). Coronavirus: How the Covid-19 pandemic could widen the gender divide. Stuff. https://www.stuff.co.nz/national/health/coronavirus/300012287/coronavirus-how-thecovid19-pandemic-could-widen-the-gender-divide

Meyers, C. (2004). Cruel choices: Autonomy and critical care decision making. Bioethics, 18(2), 104-119

Ministry for Women. (n.d.). What is bringing gender in? https://women.govt.nz/gender-tool/about$\underline{\text { tool }}$

Ministry for Women. (2016). Pacific Women. https://women.govt.nz/about/new-zealandwomen/pacific-women

Ministry for Women. (2020). COVID-19 and Women. https://women.govt.nz/news/covid-19-andwomen

Ministry of Health. (2020, June 18). COVID-19 current cases. https://www.health.govt.nz/ourwork/diseases-and-conditions/covid-19-novel-coronavirus/covid-19-current-situation/covid19-current-cases

Ministry of Social Development. (2019). Sole parent support-December 2019 quarter. https://www.msd.govt.nz/about-msd-and-our-work/publicationsresources/statistics/benefit/latest-quarterly-results/sole-parent-support.html

Ministry of Social Development. (2020). Funding for family violence services through Budget 2020. https://www.msd.govt.nz/about-msd-and-our-work/newsroom/2020/funding-for-familyviolence-services-through-budget-20.html

New Zealand Law Society. (2018). Domestic Violence Victim Protection bill passes. https://www.lawsociety.org.nz/news/legal-news/domestic-violence-victim-protection-billpasses/

PayScale. (2020). Hourly Rate for Industry: grocery store or supermarket.

https://www.payscale.com/research/NZ/Industry=Grocery_Store_or_Supermarket/Hourly_Ra $\underline{\text { te }}$

Périver, H. (2014). Men and women during the economic crisis: Employment trends in eight European countries. Revue de l'OFCE, 133(2), 41-48 https://doi.org/10.3917/reof.133.0041

Ribeiro, C. (2020, May 23). Pink-collar recession: How the COVID-19 crisis could set back a generation of women. The Guardian. https://www.theguardian.com/world/2020/may/24/pinkcollar-recession-how-the-covid-19-crisis-is-eroding-womens-economic-power

RNZ (Radio NZ). (2020a, May 16). Covid-19: Green light for sex industry to restart. https://www.rnz.co.nz/news/national/416803/covid-19-green-light-for-sex-industry-to-restart

RNZ (Radio NZ). (2020b, March 31). Supermarket staff describe abuse, stress of restocking shelves in Covid-19 lockdown. 
https://www.rnz.co.nz/national/programmes/checkpoint/audio/2018740944/supermarketstaff-describe-abuse-stress-of-restocking-shelves-in-covid-19-lockdown

Russell, R., \& Masselot, A. (2020). Why do we care? The shifting concept of care in New Zealand and the United Kingdom. International Journal of Comparative Labour Law and Industrial Relations, 36(1), 81-106

Scobie, M., \& Sturman, A. (2020). Economies of mana and mahi beyond the crisis. New Zealand Journal of Employment Relations, 45(2), 77-88

Stat NZ. (2019). Women in paid work. https://www.stats.govt.nz/news/women-in-paidwork\#: : text=Women\%20now\%20make\%20up\%20almost,are\%20in\%20part\%2Dtime\%20j obs.

Stat NZ. (2020). COVID-19 lockdown has widespread effects on labour market. https://www.stats.govt.nz/news/covid-19-lockdown-has-widespread-effects-on-labour-market

Stock, B. (2020, March 31). KiwiSaver providers told to be 'sensible and practical' on hardship withdrawal applications. Stuff. https://www.stuff.co.nz/business/betterbusiness/120696148/kiwisaver-hardship-withdrawals-rules-eased-under-covid19-lockdown

Todd, K. (2020, May 21). Sex workers struggle with contact tracing clients. RNZ (Radio NZ). https://www.rnz.co.nz/news/national/417212/sex-workers-struggle-with-contact-tracing$\underline{\text { clients }}$

UN Women. (2020). Policy Brief: the impact of COVID-19 on women. https://www.unwomen.org//media/headquarters/attachments/sections/library/publications/2020/policy-brief-the-impactof-covid-19-on-women-en.pdf?la=en \&vs=1406

Whiteford, A., \& Olsen, B., (2020). Examining the NZ Industries Hit Hardest by the COVID-19 Pandemic. Infometrics. https://www.infometrics.co.nz/examining-the-nz-industries-hithardest-by-the-covid-19-pandemic/.

WHO (World Health Organization). (n.d.). Women and Health: Female life expectancy. https://www.who.int/gho/women_and_health/mortality/situation_trends_life_expectancy/en/

Women in Super. Women and Super - why the numbers don't stack up. https://www.womeninsuper.com.au/content/the-facts-about-women-and-super/gjumzs 